\title{
ISLAM DAN PARTISIPASI POLITIK PEREMPUAN: Analisis Normatif dan Historis
}

\author{
Agus Purnomo \\ Dosen STAIN Ponorogo dan Peserta Program Doktor IAIN Sunan Ampel Surabaya
}

\begin{abstract}
Normatively, Islam gives equal access for men and women to participate in public arena. Historical reality notes in the historiography of Islam also presenting impressing "scene" about women's participation in political circumtances. In historical note, women basically are significant part and influential element for political orientation in many governances.This phenomenon, eventually inspires women's thought and movement throughout the world from egypt, Morocco, PKISTAN, India, Malaysia as well as Indonesia.
\end{abstract}

Kata kunci: sejarah, pemikiran, gerakan perempuan.

\section{A. Pendahuluan}

Kuatnya pengaruh stereotipe tentang perempuan, sebagaimana dikeluhkan para feminis masih ditemukan pada lingkungan sosial keagamaan yang bernaung di bawah label Islam. Dalam kasus-kasus tertentu, stereotipe tidak jarang menyebabkan kebingungan perempuan untuk mendefinisikan diri, termasuk dalam kerangka menentukan pilihan atau orientasi politik dan media aktualisasi diri. Hal ini karena ada semacam ketakutan yang "dianggap" menyalahi idealisasi kultural yang selama ini disandangnya.

Secara khusus, kalangan feminis menyoroti dan menggugagt kasus-kasus stereotipe di atas. Karenanya, dalam konteks ini pulalah kelompok feminis lebih menyukai penggantian penggunaan vocabulary wanita menjadi perempuan, sebagaimana ditulis Teguh Is Winarto dalam bukunya Sexisme dalam Bahasa. ${ }^{1}$

Mayling Oey-Gardiner, Evelyn Sulaeeman dan Rozydyanti ${ }^{2}$ memberikan contoh lain bagaimana strereotipe terhadap perempuan dalam dunia pendidikan juga meninggalkan persoalan tersendiri bagi perempuan berpendidikan. Pengangguran terdidik yang akhir-akhir ini banyak disoroti berbagai media, ternyata lebih banyak diisi oleh perempuan. Hal ini disebabkan oleh karena image dan stereotipe yang selama ini dicitrakan terhadap perempuan, sehingga mengakibatkan mereka mendapat perlakuan kelas dua dalam peta penyerapan tenaga-tenaga terdidik di Indonesia untuk mendapatkan lapangan pekerjaan. Kalaupun mereka terserap, namun dengan gaji dan upah yang tidak setara dengan gaji tenaga kerja laki-laki.

\footnotetext{
${ }^{1}$ Teguh Is Winarto dalam bukunya Sexisme dalam Bahasa, dalam Harian Republika tanggal 11 April 1996.

${ }^{2}$ Harian Kompas, 9 Januari 1997.
} 
Marjinalisasi terhadap kaum perempuan terjadi secara multidimensional yang disebabkan oleh banyak hal, bisa berupa kebijakan pemerintah, tafsiran agama, keyakinan, tradisi dan kebiasaan atau bahkan asumsi ilmu pengetahuan. ${ }^{3}$ Dominasi struktur dan ideologi patriarkhi telah melahirkan sikap 'laki-laki isme' pada banyak aspek kehidupan, misalnya kebijakan pemerintah yang menggunakan teknologi canggih sehingga menggantikan peran-peran perempuan di sektor yang selama ini ia bisa mengakses secara ekonomis.

Hampir dapat dipastikan bahwa terjadinya marjinalisasi perempuan ini disebabkan oleh dominasi struktur dan ideologi patriakhi, yang diyakini telah melahirkan sikap "laki-laki isme" pada banyak aspek kehidupan. Dosa patriarkhi terhadap persoalan-persoalan perempuan bahkan semakin bertambah panjang ketika ia berakomodai dan berkolaborasi dengan kepentingan-kepentingan developmentalisme, yang telah merampas hak dan meminggirkan perempuan.

Para feminis muslim juga menyorot bahwa terjadinya marjinalisasi perempuan ini berawal dari ideologi gender yang dianut oleh masyarakat, yang pada gilirannya melahirkan paham ibuisme (motherhood) dan ideologi istrinisasi (housewifezation). Paham ibuisme menganggap bahwa kodrat dan kewajiban perempuan adalah sebagai ibu, menangani pekerjaan rumah tangga, mengasuh dan mengurus anak, serta anggota keluarga lainnya. Sedangkan faham istrinisasi, sebagaimana dinyatakan Sita Aripurnami, sejalan dengan definisi perempuan dalam GBHN 1963 dan Panca Dharma Wanita. Konsep istrinisasi mengacu kepada satu proses di mana perempuan secara sosial ditempatkan sebagai ibu rumah tangga, yang kebutuhan hidupnya tergantung kepada suami, terlepas apakah secara de facto ia memang ibu rumah tangga atau bukan. Pelabelan negatif kepada perempuan akan berakibat pada tidak diakuinya potensi kaum perempuan, sehingga ia sulit mengakses posisi-posisi strategis dan sentral dalam komunitasnya, terutama yang berkaitan dengan pengambilan kebijakan dan keputusan politik.

\footnotetext{
${ }^{3}$ Mansour Faqih, Analisis Gender dan Transformasi Sosial (Yogyakarta: Pustaka Pelajar, 2001), 14.
} 


\section{B. Islam dan Hak Partisipasi Politik Perempuan: Survey Doktrinal}

Setiap manusia memiliki hak dasar atas eksistensi kemanusiaannya, yang terangkum dalam al-kulliyyah al-khamsah yang meliputi hak beragama (hifdz aldin), hak hidup (hifdz al-hayah), hak berketurunan (hifdz al-nasl), hak berfikir (hifdz al-'aql) dan hak atas harta dan memperoleh sarana kehidupan (hifdz al$m a l$ ). Manusia sebagai mahluk Tuhan yang bermartabat, memiliki multi predikat, yakni sebagai mahluk terbaik dan termulia, pemegang amanah, bertanggung jawab, memiliki hak pilih bebas, menyandang kelemahan, menyandang peran ganda serta menyimpan fitrah ber-Tuhan.

Untuk merealisasikan predikatnya di atas, Tuhan menyediakan sarana yang diperuntukkan manusia, dalam rangka mengemban tugas dan amanah sebagai khalifah, yang memiliki kewajiban untuk memakmurkan bumi dan mensejahterakan hidup. Dengan demikian, ia memiliki tanggung jawab terhadap segala jalan hidup (gelap-terang) yang telah menjadi pilihannya. Di sinilah jiwa manusia diuji, apakah ia mampu mendominasikan potensi konstruktif (taqwa) atau sebaliknya mendominasikan potensi destruktifnya (fujur), yang mengantarkannya ke jalan kehidupan yang penuh la'nat.

Oleh karena itu, diperlukan maksimalisasi fungsi pikir, dzikir dan kreativitas setiap manusia, yang berbasis pada nilai-nilai Ilahi. Dengan adanya eksploitasi terhadap perempuan, berarti ada pengingkaran dan perampasan terhadap hak dasar setiap orang bahwa ia memiliki kebebasan dan kemerdekaan berfikir dan berkreativitas (hifdz al-'aql), tidak sebaliknya menjadi obyek dan kreativitas terpasung oleh sistem ekonomi kapitalis yang menjadikan perempuan marjinal dan subordinate.

Penafsiran terhadap QS. 4:34, butir ayat yang berbicara tentang posisi dan kepemimpinan laki-laki atas perempuan, marupakan satu masalah yang sering dijadikan contoh oleh kalangan feminis muslim untuk menunjukkan bagaimana diskriminatifnya penafsiran tradisional terhadap perempuan. Bias gender berupa penempatan laki-laki di atas perempuan, selanjutnya menandai bagaimana penafsir selalu berusaha menempatkan laki-laki pada possisi superior. Karenanya, para feminis muslim menyepakati tentang perlunya memahami ayat ini melalui pendekatan kontekstual, dengan tidak hanya terpaku pada makna literalnya serta mengkaji konteks asbab al- wurud-nya.

Jika pada umumnya mufassir klasik (dari mazhab apapun) --lewat pemahaman mereka terhadap ungkapan qawwam-- menggunakan ayat ini sebagai sebuah legalitas normatif kepemimpinan laki-laki atas perempuan --dalam rumah tangga saja atau sekaligus dalam milleau dan aspek yang lebih luas, maka 
menurut Asghar Ali Engineer ${ }^{4}$, dengan hanya bersandar pada aspek literal ayat ini tidak cukup untuk menunjukkan bahwa al-Qur'an memutlakkan kepemimpinan laki-laki terhadap perempuan.

Apabila memperhatikan dua konsideran ayat tersebut (bima faddhalallahu ba'dhahum 'ala ba'dhin wa bima anfaqu min amwalihim) dan mengaitkannya dengan QS.2:228, maka sebenarnya ayat tersebut hanya berbicara tentang kepemimpinan rumah tangga (suami terhadap istri) dan inipun hanya dalam konteks fungsi ekonomisnya. Konsideran ayat tersebut adalah kalimat bima faddhalallahu ba'dhahum 'ala ba'dhin dan bukan bima faddhalallahu ba'dhahum 'ala ba'dhihinna, merupakan respon A-Qur'an terhadap fenomena bahwa tidak semua laki-laki memiliki kelebihan atas yang lain (atas laki-laki maupun perempuan). Hal ini dimungkinkan ada sebab cacat jasmaninya sehingga si lakilaki tersebut tidak mampu memberikan nafkah terhadap keluarga, atau cacat rohani sehingga tidak mampu memimpin keluarganya dan sebagainya. Dengan demikian, menurut penafsiran kontekstual, kepemimpinan laki-laki atas perempuan juga bersifat kontekstual. Sebagai konsekuensinya, perempuan bisa menjadi pemimpin, baik dalam keluarga maupun dalam jabatan-jabatan di sektor publik, seperti jabatan politik.

Interpretasi yang menganggap bahwa kepemimpinan laki-laki atas perempuan tersebut normatif sifatnya, mendukung interpertasinya dengan Hadis Nabi tentang tidak sejahteranya sebuah bangsa yang menyerahkan kepemimpinannya pada kaum perempuan (HR. Al-Bukhari). ${ }^{5}$ Hadis tersebut sesungguhnya bisa dimaknai dalam konteks sebagai berikut: pertama, hadis tersebut berlaku khusus, yakni respon basyariah (aspek kemanusiaan) Nabi terhadap pengangkatan putri Kisra, Bahram binti Kisra sebagai kaisar yang menggantikannya; kedua, hadis tersebut bersifat informatif sehingga tidak memiliki relevansi hukum jika ditarik sebagai justifikasi larangan kepemimpinan perempuan secara umum; ketiga, kapasitas dan kapabilitas putri Kisra perlu dipertanyakan mengingat situasi dan kondisi secara umum masyarakat Persia saat itu, yang tidak memberikan keleluasaan kepada perempuan untuk mengakses dunia publik; keempat, beberapa kalangan --terutama kalangan feminis muslim-juga mempertanyakan status dan validitas hadis tersebut, baik dari aspek sanad maupun matannya. Meskipun penulis berkeyakinan akan kesahihan validitas sanad hadis tersebut, namun pemahaman kontekstual, dengan mengkaji secara

\footnotetext{
${ }^{4}$ Asghar Ali Engineer, Islam dan Hak-hak Perempuan (Yogyakarta : LSPPA, 2000), 63.

${ }^{5}$ Hadis tersebut seringkali digunakan oleh sejumlah kalangan Islam sebagai legitimasi bagi pelarangan kaum perempuan menjadi pemimpin atau menduduki jabatan publik
} 
serius aspek-aspek yang mendasari atau melatari munculnya teks hadits (asbab wurud al-hadits) sebagaimana yang digagas al-Syafi'i perlu menjadi pertimbangan penting.

Jika pada masa awal-awal kelahirannya, Islam identik dengan isu dan wacana pembebasan perempuan, maka kini ada kecenderungan "warna" Islam yang identik dengan pembatasan terhadap perempuan. Di penghujung abad ini banyak negara Islam melakukan revolusi dan reformasi dengan mengambil tema keislaman. Namun demikian, seringkali yang terjadi di pasca-revolusi dan reformasi adalah pengekangan terhadap perempuan. Islamisasi suatu negara seolah-olah berarti "merumahkan" perempuan atau jilbabisasi perempuan. Iran, Pakistan, Aljazair, dan Afganistan dapat menjadi contoh dari fenomena tersebut. Bagaimana Islam dijadikan dalil untuk mencopot pegawai negeri di sejumlah daerah di Afghanistan dengan alasan perempuan tidak boleh bekerja di bidang publik. $^{6}$

Jika dikembalikan pada konsep dasar Islam, yakni prinsip tauhid, maka dapat dimaknai bahwa siapapun tidak diperkenankan menghambakan dirinya kepada selain Tuhan, termasuk pada popularitas, materi, sistem ekonomi dan sebagainya. Semua kebebasan dan hak-hak yang dimiliki seseorang bukanlah kebebasan yang bersifat absolut (tanpa batas). Ia mempunyai kewajiban yang dibebankan Allah kepadanya, yakni patuh terhadap perintah dan larangan-Nya. Perintah-Nya adalah agar manusia berbuat baik dan tidak mengutamakan kepentingan diri sendiri. ${ }^{7}$ Dengan demikian, kebebasan dalam Islam memiliki batasan-batasan. Jika seseorang merampas nyawa orang lain, maka hak hidupnya sendiri terganggu oleh perbuatan melanggar hak hidup orang lain. Hak hidupnya hilang karena perbuatannya itu. ${ }^{8}$ Hak mengumpulkan harta harus diimbangi dengan kewajiban mengumpulkannya secara halal serta mentasharrufkannya di jalan Tuhan dan sebagainya. Sebagai implementasi dari hak dasar kemanusiaan di atas, setiap laki-laki maupun perempuan memiliki hak untuk menyalurkan dan mengaktualisasikan dirinya dalam setiap sendi dan ruang kehidupan, sesuai dengan kapasitas dan kapabilitasnya.

Secara normatif, Islam telah memberikan sinyalemen kesamaan hak dalam partisipasi setiap aspek kehidupan. Namun dalam realitas kehidupan, masih saja terjadi kesenjangan antara idealita dan realita. Sejarah pergolakan dunia Islam, tidak meninggalkan sedikitpun partisipasi kaum perempuan dalam menentukan

\footnotetext{
6 Nasaruddin Umar, Teologi Pembebasan Perempuan, http://islamlib.com/id/index.php ?page $=$ article $\& i d=90,29 / 07 / 2001$, diakses 20 Oktober 2008.

${ }^{7}$ Al-Qur'an, Surat: al-Hasyr (59): 9.

${ }^{8}$ Al-Qur'an, Surat: al-Baqarah (2): 178 dan 179.
} 
arah dan mewarnai corak pemerintahan negara bangsa. Namun, dalam penulisan historiografi Islam, partisipasi politik para perempuan ini tidak banyak dicatat dalam lembaran sejarah kehidupan. Hal ini karena tipikal sejarah dunia bercita rasa androsentris. Karenanya, istilah history (sejarah laki-laki) lebih populer daripada herstory (sejarah perempuan). Bahkan istilah yang disebutkan terakhir ini hampir tidak dikenal dalam khazanah intelektual dunia. 


\section{Islam dan Partisipasi Politik Perempuan: Survey Historis}

Pada awal-awal sejarah Islam, kaum perempuan memperoleh kemerdekaan dan suasana batin yang cerah. Rasa percaya diri mereka semakin kuat sehingga di antara mereka terdapat sejumlah orang yang mampu menorehkan catatan prestasi gemilang, bukan saja di dalam sektor domestik tetapi juga di sektor publik. Sayang sekali kenyataan seperti ini tidak berlangsung lama karena banyak faktor. Antara lain, semakin berkembangnya dunia Islam hingga mencapai pusat-pusat kerajaan yang bercorak misoginis seperti Damaskus, Bagdad dan Persia. Di samping itu, unifikasi dan kodifikasi kitab-kitab hadis, tafsir, dan fikih, yang banyak dipengaruhi oleh budaya lokal, secara langsung maupun tidak langsung turut memiliki andil besar di dalam persoalan memberikan pembatasan hak dan gerak kaum perempuan. ${ }^{9}$

Pada saat bersamaan, secara simultan juga telah berlangsung politik antropologi untuk melanggengkan tradisi patriarkhi yang menguntungkan kaum laki-laki. Berbagai nilai diarahkan dan digunakan untuk mempertahankan keberadaan pola relasi gender yang berakar dalam masyarakat. Karena hal tersebut berlangsung cukup lama, maka pola itu mengendap di alam bawah sadar masyarakat, seolah-olah pola relasi gender adalah kodrat. ${ }^{10}$ Kondisi ini bertambah kuat lagi setelah pola relasi kuasa (power relations) menjadi subsistem dalam masyarakat modern-kapitalis, yang kemudian melahirkan masyarakat patriarkhi baru (new patriarchy).

Semakin kuat pola relasi kuasa, maka semakin besar pula ketimpangan peran gender di dalam masyarakat, karena seseorang akan diukur berdasarkan nilai produktivitasnya. Dengan alasan faktor reproduksi, maka produktivitas perempuan dianggap tidak maksimal sebagaimana kaum laki-laki. Perempuan diklaim sebagai komunitas reproduksi, yang lebih tepat mengambil peran domestik, dan laki-laki diklaim sebagai komunitas produktif, yang lebih tepat mengambil peran publik. Hal ini mengakibatkan terciptanya suatu sistem struktural dan kultural masyarakat yang didominasi oleh jenis kelamin laki-laki (al-mujtama' al-abawiy).

Bahkan jika dirunut sejarah perjuangan perempuan, baik sebelum Islam datang, pada saat awal-awal pertumbuhan Islam, terdapat panorama indah yang menyajikan catatan kiprah strategis perempuan dalam kancah perpolitikan dan sangat menentukan nasib rakyat dan bangsanya. Sebut saja Ratu Balqis yang

\footnotetext{
9 Nasaruddin Umar, Teologi Pembebasan Perempuan, http://islamlib.com/id/index.php ?page $=$ article \&id=90, 29/07/2001, diakses 20 Oktober 2008.

${ }^{10}$ Kodrat dalam bahasa Arab berasal dari kata qudrah yang berarti (sesuatu yang) ditentukan oleh Tuhan.
} 
mampu memimpin dan membawa bangsanya menjadi negeri yang sejahtera dalam naungan dan ridha Ilahi (baldatun thayyibatun wa rabbun ghafur), Aisyah yang pernah memimpin perang menghadapi Ali dalam Perang Unta (Jamal).

Tritton dan Shalabi menyebut ada sebanyak 1543 ulama perempuan, dan banyak di antaranya merupakan pimpinan khalaqah dan lembaga pendidikan yang melahirkan ulama-ulama besar, tidak saja laki-laki tetapi juga perempuan. Bahkan di antara sejumlah guru atau orang-orang yang meriwayatkan hadis kepada Imam Malik --salah satu pendiri empat madzhab-- memiliki jalur periwayatan hadis dari thabaqat sahabat sebanyak 85 orang sahabat laki-laki dan 20 orang sahabat perempuan. $^{11}$

Demikian juga sejarah Indonesia, yang pernah mencatat kepemimpinan empat ratu (sultanah) di Aceh, sebuah negara kesultanan yang berafiliasi secara teologis dan politis ke Turki Usmani, Aisyah Lemu di Ternate, dan bahkan kepeloporan perempuan muslimah dalam memperjuangkan harkat dan martabat perempuan bangsa Indonesia, seperti yang dilakukan oleh RA. Kartini di Jawa, Rahmah El-Yunusiyah di wilayah Sumatera Barat, Nyi Ageng Serang di Banten, dan peran Cut Nyak Dien di bumi Serambi Mekkah dan sebagainya. Untuk konteks saat ini, kita bisa menyebut nama Wardah Hafid, Nurul Agustina, Ratna Megawangi, hingga mantan first lady Indonesia, Sinta Nuriyah Abdurrahman Wahid juga berada di garda terdepan dalam upaya membela dan membekali kaum perempuan. Munculnya "Teologi Perempuan" yang menjadi "akidah-akidah" baru yang mengagendakan pembebasan dan pemberdayaan kaum perempuan, tampaknya juga menjadi suatu keniscayaan sejarah, dalam kerangka membela hak-hak perempuan.

Dalam konteks Indonesia, dapat dinyatakan bahwa perempuan adalah mayoritas penduduk Indsonesia dan pada saat yang sama merupakan jumlah pemilih (voters) yang mayoritas. Namun, kemayoritasannya kurang tercermin dalam keterwakilannya hampir di setiap institusi politik. Hal ini berdampak pada kurang adanya perhatian terhadap kepentingan perempuan. Bahkan dalam perdebatan dan wacana perpolitikan kita, isu-isu besar yang berkaitan dengan perempuan seringkali tidak terjamah dan bahkan tidak dianggap sebagai masalah penting yang harus direspon dan disikapi secara proporsional. Masalah pendidikan, ketenagakerjaan, ekonomi, hukum, kesehatan, sosial dan budaya, bahkan negara maupun militer, juga kurang merangkum dan mengcover isu dan memperhatikan kepentingan perempuan.

\footnotetext{
${ }^{11}$ Raja' Musthafa Khazin, A'lam a-Muhadditsin Wa Manahijuhum fi al-Qarn al-Tsani wa al-Tsalits alHijri (Kairo: Universitas Al-Azhar, tth.), 35.
} 
Ketika perempuan tidak banyak telibat secara formal pada institusiinstitusi politik, bukan berarti bahwa perempuan terabaikan dari dampak dan pengaruh citra politik. Bahkan seringkali perempuan hanya dijadikan sebagai obyek politik atau isu politik ketika partai-partai politik tertentu melakukan kampanye. Namun setelah mendapatkan dukungan politik dari kaum yang mayoritas ini, kepentingan konstituen ini ternyata tidak terakomodasi, baik dalam perencanaan, pelaksanaan, monitaring maupun evaluasi kebijakan dan program kerja partai. Dalam konteks demikian lagi-lagi terbukti ada peminggiran terhadap eksistensi maupun kepentingan perempuan yang hanya dianggap sebagai mahluk peripheral.

Otonomisasi daerah di Indonesia dengan memberikan peran lebih besar kepada tokoh-tokoh adat dan agama setempat, juga tidak menutup kemungkinan akan adanya upaya menjadikan perempuan sebagai sasaran dan obyek. Kita tentu sangat berharap agar Islam tidak lagi dijadikan sebagai suatu kekuatan ideologis yang digunakan sebagai "alat" untuk menekan suatu kelompok atau jenis kelamin tertentu dan sebaliknya memberikan keuntungan kepada kelompok atau jenis kelamin yang lain.

Di Jepang, kita juga bisa menjumpai Michiko sebagai tokoh pergerakan kaum perempuan. Maroko juga memiliki pemikir dan feminis muslimah, yakni Fatima Mernissi. Ashgar Ali Engineer dan Rifat Hassan dari India, Amina Wadud Muhsin dari Malaysia, merupakan serentetan tokoh pemikir dan pejuang perempuan, yang berupaya menegakkan kesetaraan dan keadilan, baik dari aspek teoretis pemikiran maupun praksis gerakan.

Di dunia Arab sendiri, khususnya Mesir, masalah relasi gender ini menjadi bagian dari problem-problem sentral (al-isykaliyât al-markaziyah) dari pergolakan pemikiran di negeri Pyramid ini. Huda Sya'rawi, Zaenab Fawwaz, Nawwal Sa'dawi, May Ziyadah, Aisha Taymoriah, dapat kita sebut sebagai eksemplarnya. Namun demikian, jika kita mencoba menarik sejarah aksi-aksi para feminis ini ke belakang, maka Qasim Amien-lah, yang menciptakan mainstream dan aksi-aksi kaum Hawa ini. Pemikiran Amin tentang perempuan ini dapat dijumpai dalam tulisannya, Tahrir al-Mar'ah dan al-Mar'ah al-Jadidah, ${ }^{12}$ dua karya besar yang banyak menginspirasi pemikiran dan gerakan perempuan.

Karena itu, pada saat kita berbicara tentang gerakan feminisme di Arab maka tidak akan lepas dari pembicaraan tentang Qasim Amien, seorang tokoh

\footnotetext{
12 Karya Amin ini dalam versi terjemahnya diartikan sebagai Sejarah Penindasan Perempuan: Menggugat "Islam Laki-laki" Menggurat "Perempuan Baru", yang dialihbahasakan oleh Syariful Alam dengan penerbit IRCiSoD Yogyakarta pada tahun 2003.
} 
yang berjasa dalam pergerakan pembebasan kaum perempuan Arab khususnya dan kaum perempuan muslimah di negara-negara Dunia Ketiga pada umumnya. Qasim Amien dijuluki sebagai Bapak "Feminisme" Arab. ${ }^{13}$ Namanya dikenang sebagai pejuang kebebasan perempuan dari segala bentuk diskriminasi. Di samping itu, pemikiran brilliant Amin ini juga banyak mempengaruhi para pejuang pergerakan feminisme yang datang setelah zamannya.

Sebagaimana pemikiran tokoh-tokoh yang lain, pemikiran seorang tokoh tidak akan lepas dari permasalahan pro dan kontra. Apalagi jika pemikiran dan gerakan tersebut mengusung reformasi yang gegap gempita pada saat itu. Demikian halnya pemikiran Amien. Gagasan Amin tentang perempuan berangkat dari analisis sosial, hingga kritik atas teks-teks keagamaan yang dipahami masyarakat muslim pada umumnya sebagai tradisi yang profan dan tunduk pada nilai sosial dan sejarah. Pemikiran Amin bahkan dinilai mampu meruntuhkan "tembok" kejumudan berpikir dan menjadi "shock theraphy" dari permasalahanpermasalahan yang menjadi "blunder" dalam masyarakat masa itu.

Bukti-bukti historis di atas, menjadi point penting yang mengingatkan kepada kita bahwa perempuan sesungguhnya senantiasa memiliki kontribusi besar bagi dunia perpolitikan Islam. Oleh karena itu, jika masih ada pemahaman bahwa perempuan tidak absah menjadi pemimpin, sama artinya kita bersikap a historis, bahkan memutar sejarah ke belakang (set back) yang berarti adalah kemunduran dan bahkan bisa disebut sebagai upaya "pembodohan" sejarah.

Namun, satu hal yang perlu menjadi catatan kita semua adalah bahwa keabsahan dan kelayakan seseorang menjadi pemimpin, sangat tidak ditentukan oleh faktor jenis kelaminnya (laki-laki atau perempuan) tetapi karena abilitas dan kapabilitasnya untuk menjadi seorang leader dan pemimpin, dan bukan penguasa. Logika pemimpin adalah tidak relasi hirakhial dengan pola ada atasan-bawahan atau ada patron-klien dalam arti substantif, sementara logika penguasa adalah bentuk relasi hirarkhial dengan pola patron-klien yang cenderung hegemonik dan bahkan opresif.

\section{Kesimpulan}

\footnotetext{
${ }^{13}$ Menurut sebagian kalangan feminis perempuan, Qasim Amien bukan pelopor gerakan pembebasan perempuan, karena pada masa sebelum Qasim, telah dikenal tokoh-tokoh feminisme dari kalangan perempuan. Pemikiran Qasim Amien terkenal gara-gara sistem sosial yang patriarkhi, maka tokohtokoh dari kalangan laki-laki, termasuk Qasim Amien lebih banyak dikaji dan "diamini" dari pada feminisme dari kalangan perempuan. (Nawwal Al-Sa'dawi, Qadhâyâ al-Mar'ah wa al-Fikr wa alSiyâsah, Kairo: Madbouli,. 2001), cet 1, 81.
} 
Secara normatif, baik al-Qur'an maupun al-Hadits, banyak memberikan ruang gerak kepada perempuan untuk berkiprah di dunia publik. Al-Qur'an juga menggambarkan bahwa laki-laki dan perempuan adalah sama-sama bagian dari bangsa manusia yang satu, keturunan Adam yang dimuliakan Allah, serta mahluk yang setara, yang ukuran ketidaksetaran keduanya hanya ada pada parameter ketaqwaannya kepada Allah. Illustrasi menarik dari beberapa ayat al-Qur'an di atas, mengindikasikan bahwa semua orang, baik laki-laki maupun perempuan memiliki akses yang setara untuk berkarir di dunia publik, termasuk menjadi pemimpin dan memasuki kancah politik.

Historisitas peran perempuan dalam kancah perpolitikan, mulai dari masa sebelum hadirnya Islam, era awal kehadiran dan pertumbuhan Islam hingga era sekarang, sesungguhnya merupakan rujukan sejarah yang dapat dijadikan sebagai penuntun bagi perjuangan perempuan masa-masa selanjutnya. Torehan sejarah dan panorama indah berupa partisipasi perempuan dalam kancah perpolitikan di dunia Islam bahkan hingga di Indonesia, merupakan bukti yang tidak terbantahkan bahwa perempuan merupakan bagian dari pelaku sejarah, dan bukan semata obyek sejarah. Wa Allah a'lam bi al-shawab. 


\section{BIBLIOGRAFI}

Al-Qur'an, Surat: al-Baqarah (2): 178 dan 179.

Al-Qur'an, Surat: al-Hasyr (59): 9.

Al-Sa'dawi, Nawwal. Qadhaya al-Mar'ah wa al-Fikr wa al-Siyasah. Kairo: Madbouli, 2001, cetakan 1.

Amin, Qasim. Sejarah Penindasan Perempuan: Menggugat "Islam Laki-laki" Menggurat "Perempuan Baru", terj. Syariful Alam. Yogyakarta: IRCiSoD, 2003.

Engineer, Asghar Ali. Islam dan Hak-hak Perempuan Yogyakarta : LSPPA, 2000.

Faqih, Mansour. Analisis Gender dan Transformasi Sosial. Yogyakarta: Pustaka Pelajar, 2001.

Harian Kompas, tanggal 9 Januari 1997.

Khazin, Raja' Musthafa, A'lam a-Muhadditsin Wa Manahijuhum fi al-Qarn al-Tsani wa al-Tsalits al-Hijri. Kairo: Universitas Al-Azhar, tth.

Umar, Nasaruddin. Teologi Pembebasan Perempuan, http://islamlib.com /id/index.php ?page=article\&id=90, 29/07/2001, diakses 20 Oktober 2008.

Winarto, Teguh Is "Sexisme dalam Bahasa", dalam Harian Republika tanggal 11 April 1996. 